\title{
Did ash fall from Puyehue-Cordón Caulle volcanic complex affect ant abundance and richness in the Patagonian steppe?
}

\author{
Gabriela I. Pirk
}

Laboratorio Ecotono, INIBIOMA, CONICET - Universidad Nacional del Comahue Bariloche, Argentina

\begin{abstract}
Aвstract. Natural disturbances are important components of ecosystem dynamics. Large scale disturbances produced by volcanoes, have been poorly studied because of their low frequency, the lack of baseline studies due to their unpredictability, the impossibility of replication, and the difficulty of conducting long-term studies to monitor ecosystem recovery. The recent eruption of the Puyehue-Cordón Caulle volcanic complex (June 2011), which produced an ash fall covering 24 million ha of Patagonia, provides a unique opportunity of studying this type of disturbance in areas with baseline data. The summer before the ash fall (2011) ant communities were characterized in areas of the Patagonian steppe which were later covered with $4 \mathrm{~cm}$ of fine ash. The aim of this study is to establish if ash deposition affected ant abundance, species richness and composition. In summers 2012 and 2013, sampling was repeated and data obtained were compared among years. Total ant abundance tended to be lower after the eruption, but species richness and composition were similar before and two seasons after the ash fall. The little effects on ant community is mainly a consequence of the timing of the eruption, ants' social nature, and ash thickness. The eruption occurred at the end of the autumn when ant activity was reduced due to low temperatures. Also, the potential mortality of outside workers during the acute deposition phase does not risk colony survival since they represent a small percentage of it. Ash thickness was probably not high enough to produce severe effects. Only four out of 13 species changed their incidence after the ash fall, three of them not until the second season, showing a delayed response. This was probably a consequence of indirect effects mediated by resource and environmental changes. Long-term effects on other species cannot be discarded.
\end{abstract}

[Keywords: Argentina, desert, Formicidae, natural disturbance, volcanic eruption]

RESUMEN: ¿Afectó la lluvia de cenizas del complejo volcánico Puyehue-Cordón Caulle la abundancia y riqueza de hormigas en la estepa patagónica?: Las perturbaciones naturales constituyen componentes fundamentales en la dinámica de los ecosistemas. Aquellas de gran escala, como las ocasionadas por huracanes y volcanes, han sido poco estudiadas debido a su baja frecuencia, la ausencia de información de base por su baja predictibilidad, la imposibilidad de replicación y la dificultad de realizar estudios a largo plazo que evalúen la recuperación de los ecosistemas. La reciente erupción del complejo volcánico Puyehue-Cordón Caulle (junio 2011) cuya lluvia de cenizas cubrió 24 millones de hectáreas de la Patagonia, brinda una oportunidad única para estudiar este tipo de perturbación con información de base. El verano previo a la erupción se caracterizaron las comunidades de hormigas en áreas de la estepa patagónica posteriormente cubiertas por $4 \mathrm{~cm}$ de cenizas finas. El objetivo de este estudio es establecer si la deposición de cenizas afectó la abundancia, riqueza y composición de hormigas. Durante los veranos 2012 y 2013 se repitió el muestreo y los datos fueron comparados entre años. La abundancia tendió a ser menor después de la erupción, pero la riqueza y composición de hormigas fueron similares antes y dos temporadas posteriores a la erupción. El escaso efecto se debe principalmente al momento de la erupción, a que las hormigas son insectos sociales y al espesor de la capa de cenizas. La erupción ocurrió a fines de otoño cuando la actividad de las hormigas es reducida por las bajas temperaturas. Aun habiendo existido mortalidad de obreras durante la deposición, éstas representarían un bajo porcentaje de la colonia, garantizando su supervivencia. Solo cuatro de 13 especies cambiaron su incidencia, tres de ellas recién en la segunda temporada. Este retardo en la respuesta podría estar mediado por cambios en los recursos y el ambiente. No se descartan posibles efectos a largo plazo en las otras especies.

[Palabras clave: Argentina, desierto, erupción volcánica, Formicidae, perturbación natural]

\section{INTRODUCTION}

Natural disturbances are important components of ecosystem dynamics (Pickett \& White 1985). Their ecological consequences are variable and depend on their nature, frequency and extent. Relatively small, frequent disturbances have been very well documented in the past decades. However,

Editora asociada: Adriana Ruggiero

gabriela.pirk@crub.uncoma.edu.ar large scale natural disturbances, such as those produced by volcanoes, have been much less studied (Turner et al. 1997). This is probably a consequence of their low frequency, the lack of baseline studies due to their unpredictability, the impossibility of replication, and the difficulty of conducting long-term studies to monitor ecosystem recovery. There are some exceptions of well studied volcanic eruptions 
(e.g., Mt. St. Helens eruption in 1980; Dale et al. 2005) but lack of information on the system's conditions before them is a common feature in available studies.

Volcanic activity can have immediate and devastating physical impacts on ecosystems surrounding the eruption sites (Halpern et al. 1990; Grishin et al. 1996). However, some events such as ash fall can cover large geographical areas and remain in the system for a long time. Thus, it not only has strong direct effects on the biota, through the immediate mortality of plants and animals and the massive loss of habitat; its indirect effects, such as delayed mortality due to lack of resources or changes in interactions among organisms, can be relevant yet less obvious (Arendt et al. 1999).

Insect populations can be negatively affected by ash fall as they are killed mainly through desiccation, resulting from abrasion of the cuticle (Brown \& bin Hussain 1981; Edwards \& Schwartz 1981). In the acute deposition phase the impact may be radical, affecting insect populations quantitatively. During the chronic phase of exposure, however, effects may be more qualitative through the loss of more susceptible insect populations and/or the increase of more tolerant ones (Buteler et al. 2011). The magnitude of the effects depends on several factors, such as the thickness of the ash deposit, timing of the eruption, and insect taxon, as was observed in Mount St. Helens ash fall (spring 1980). In areas with $2-3 \mathrm{~cm}$ of ash deposit, only a temporary reduction of epigeous insect populations was recorded (Akre et al. 1981; Klostermeyer et al. 1981). However, populations of yellowjacket wasps were devastated where the ash deposit was 3 $\mathrm{cm}$, probably due to mortality of overwintering queens (Akre et al. 1981). In Costa Rica, ash from Irazú volcano (1962 and 1965) negatively affected wasps and bees through the ingestion of contaminated nectar and the destruction of the vegetation they depended on, but favored other resistant wax-covered insects, whose natural enemies were reduced (Wille \& Fuentes 1975). Thus, net effects of ash on insect populations result from the interaction of several factors, becoming very difficult to predict without information on the affected system.

The Puyehue-Cordón Caulle volcanic complex (40 $40^{\circ} \mathrm{S}, 72^{\circ} 10^{\prime} \mathrm{W}$; Chile) is one of the at least 50 volcanoes that define the $1400 \mathrm{~km}$ - long Andean Southern Volcanic Zone (Singer et al. 2008). Its latest eruption took place on June $4^{\text {th }} 2011$ and shed about 950 million tons of volcanic ash into the atmosphere, covering 24 million ha of Patagonia (Gaitán et al. 2011). The prevailing westerly winds defined a W-E decreasing gradient of ash cover and particle size, comprising forests, shrublands and steppes. A few recent studies show that this ash fall had an impact on some insect groups. Laboratory bioassays found that fine ash thoroughly adheres to body surfaces of two species (Coleoptera) and are toxic when mixed into the substrate at low concentration (Buteler et al. 2011). Also, mortality in adult grasshoppers was induced by constant exposure to volcanic ash using fans to simulate wind gusts (Fernandez-Arhex et al. 2013). A set of experiments showed that in honeybees (Apis mellifera) there is no mechanism to prevent ingestion of ash-contaminated food that ultimately reduces survival, indicating that ant-pollinator relationships could be altered (Martínez et al. 2013). Finally, populations of the invasive wasp Vespula spp. were completely devastated in areas where ash thickness was $>3 \mathrm{~cm}$ (Masciocchi et al. 2013).

Insect populations may be especially vulnerable to volcanic ash in the Patagonian steppe, where fine ash cover reached $5 \mathrm{~cm}$ (Gaitán et al. 2011). First, in these arid areas, ash remains dry for long periods of time, and since ash shows high insecticide effects in low humidity environments, insects are subjected to long stressful conditions (Edwards \& Schwartz 1981). Second, fine ash particles are more toxic than coarse ones of similar composition (Buteler et al. 2011). Finally, vegetation was affected in the steppe, with lower presence of species in gaps than before the ash fall and no recruitment of annuals (Ghermandi \& González 2012). Since plants provide food and/or shelter for many insect species, this implies that insect populations may also be indirectly affected through ashderived changes in resource quality and abundance.

In the summer prior to the ash fall (2011), ant communities were studied in roadsideassociated sites within $\sim 1000$ ha of the Patagonian steppe. This area of the steppe was later covered with 3-5 $\mathrm{cm}$ ash (Gaitán et al. 2011), providing a unique opportunity of studying the effects of ash fall on ants with baseline information. The aim of this study is to 


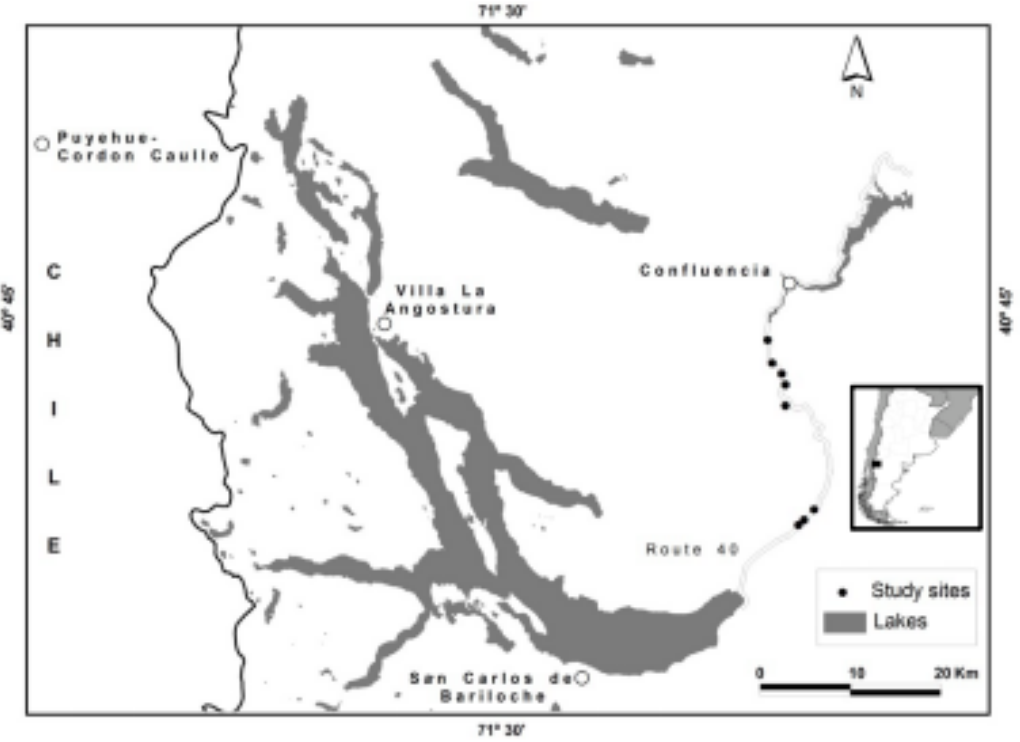

Figure 1. Map of the study area showing the location of the eight study sites.

Figura 1. Mapa del área de estudio mostrando la ubicación de los ocho sitios de estudio. establish if ash deposition had an effect on ant abundance, species richness and composition in the Patagonian steppe. The same sampling as in 2011 was repeated in summers 2012 and 2013 because reductions in ant abundance are expected to be noticeable in the first season after the eruption as the result of the direct ant mortality, while changes in ant richness and composition may arise later on, as a result of species-specific susceptibly to ash and indirect effects through changes in resources and interactions among organisms.

\section{MAterials \& Methods}

\section{Study site}

The study was carried out at the eastern border of the Nahuel Huapi National Park, located in northern Patagonia, Argentina $\left(41^{\circ} \mathrm{S}, 72^{\circ} \mathrm{W}\right)$. Eight study sites were established along national route 40 , at 30-60 km from Bariloche (Figure 1). Sites were located $>1 \mathrm{~km}$ apart along the route. These roadside areas are characterized by a mix of native species typical of the Patagonian steppe (e.g., Pappostipa speciosa, Mulinum spinosum, Imperata condensata, Oenothera odorata) and exotic herbs (e.g., Bromus tectorum, Onopordon acanthium, Carduus thoermeri and Verbascum thapsus) (Correa 1969-1998). The abundance of exotic herbs declines abruptly with distance from the road giving way, at $>50 \mathrm{~m}$, to dominant native species, such as Pappostipa speciosa and Mulinum spinosum (Farji-Brener 1996). Mean annual temperature in this area is $8^{\circ} \mathrm{C}$ and mean annual rainfall is about $600 \mathrm{~mm}$.

On June $4^{\text {th }}$ and $5^{\text {th }} 2011$, ash from PuyehueCordón Caulle volcanic complex covered the study area (Figure 2). Samples taken in Confluencia (Figure 1) two days after the eruption, showed that ash deposits consist of fine particles $(<0.01 \mathrm{~mm})$. Chemical analyses performed by CNEA (Comisión Nacional de Energía Atómica) revealed the prevalence of $\mathrm{SiO}_{2}(70 \%)$ and $\mathrm{Al}_{2} \mathrm{O}_{3}(15 \%)$, followed by $\mathrm{Na}_{2} \mathrm{O}(6 \%), \mathrm{Fe}_{2} \mathrm{O}_{3}(4 \%), \mathrm{K}_{2} \mathrm{O}(3 \%), \mathrm{CaO}(1 \%)$, $\mathrm{MgO}(1 \%)$ and $\mathrm{TiO}_{2}(<1 \%)$ (R. Daga, CNEA, pers. comm.). According to Gaitán et al. (2011) `s map, the thickness of accumulated ash within the affected
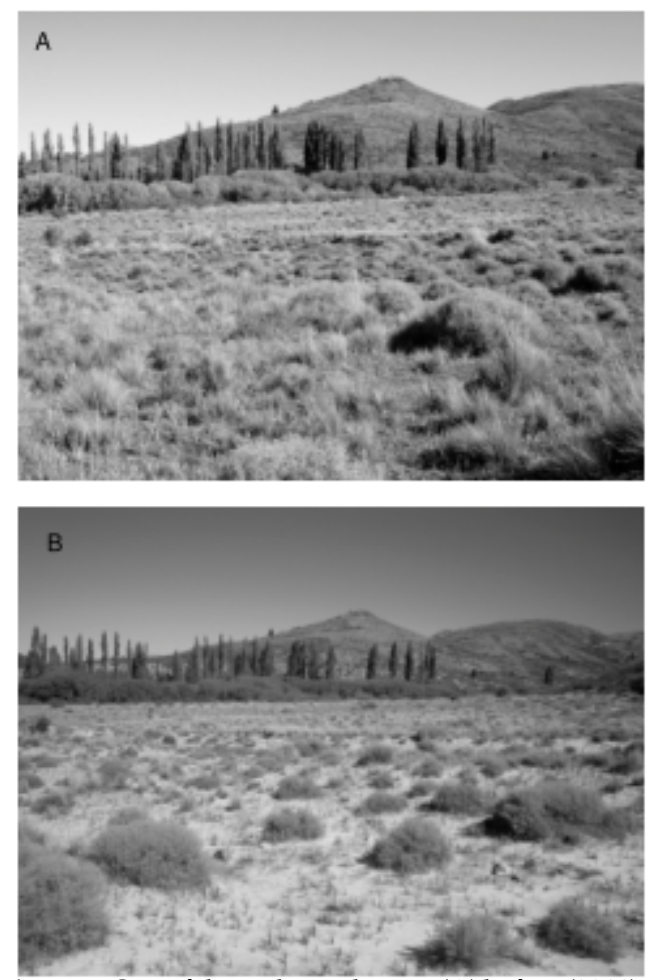

Figure 2. One of the eight study sites (A) before (2011) and (B) after (2012) the ash fall. (Photo credits, G. Pirk).

Figura 2. Uno de los ocho sitios de estudio (A) antes (2011) y (B) después (2012) de la caída de cenizas (Fotos, G. Pirk). 
area was between 3-5 cm (3-55 days after eruption; Gaitán et al. 2011). In January 2012, ash thickness was measured in 50 points per study site. Mean ash thickness across sites was $3.7 \pm 0.6 \mathrm{~cm}$ (Figure 3 ). Also, the volcano kept emanating very fine ash for a couple of months after the eruption, which made the atmosphere hazy when the prevailing wind direction was SE.

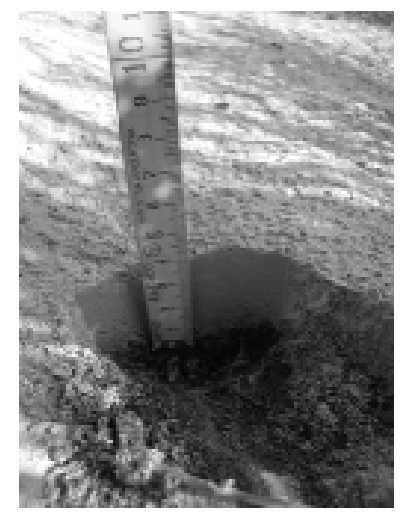

Figure 3. Ash accumulation profile in the study area in January 2012 (Photo credits, G. Pirk).

Figura 3. Perfil de acumulación de ceniza en el área de estudio en enero 2012 (Foto, G. Pirk).

\section{Sampling}

At the end of summers 2011, 2012 and 2013 (mid-February to mid-March), epigaeic ants were collected using ten pitfall traps per site. They were spread apart $\geq 10 \mathrm{~m}$, and stratified by distance to the road ( 5 close to the road and 5 at $>100 \mathrm{~m}$ from the road; $\mathrm{N}=80$ per year) to encompass the potential variability in ant communities associated to roads (Samways et al. 1997). Traps were placed at exactly the same spot each year. They consisted of plastic containers ( $9 \mathrm{~cm}$ deep, $8 \mathrm{~cm}$ wide) buried flush to the soil surface. Propylene glycol (40\%) was poured inside them and a few inodorous detergent drops were added to break surface tension. Traps remained open for seven days during the period mentioned above and then were covered and taken to the laboratory.

In the laboratory ants were separated from the content of the traps under a stereoscopic microscope. Workers were counted and identified to species when possible with the aid of existing taxonomic keys (Snelling \& Hunt 1975; Kusnezov 1978) and a reference collection of ants of the area (Laboratorio Ecotono, INIBIOMA, CONICETUNCOMA).

\section{Statistical Analyses}

To compare abundance of ant species among years, the proportion of traps in which each species was present (i.e., the incidence) was calculated per site. This variable was preferred to number of individuals per species since the latter may overestimate ant abundance. This is due to the fact that ants are central place foragers and traps may gather a high number of individuals if they are located close to the nest entrance. However, incidence could not be used to analyze total ant abundance since all traps contained ants. Instead, number of ants was used in this analysis. In spite of the potential overestimation, since traps were placed at the same spot each year, the bias associated with closeness to colonies was likely similar each year. This makes comparisons among years (i.e., the main focus of this study) reliable. Finally, species richness was defined as the number of species collected per site. For each estimated variable (i.e., total ant abundance, species incidence and species richness), the value per site was obtained as the mean value across areas (i.e., close and far from the road).

Total ant abundance, species incidence and species richness were compared among years by means of one-way blocked ANOVAs, where sites were random blocks, and year was the main factor. When year resulted significant, Tukey comparisons were performed. Variables which did not fulfill assumptions were ln or square root transformed. Throughout the three seasons, four traps were lost to livestock trampling or were cracked. To make comparisons between years accurate these traps and the ones placed at the same spot in other seasons were not considered for analyses. Thus, the total number of traps considered was 76 per year, giving a total of 228 .

To compare ant composition among years an Analysis of Similarity (ANOSIM) with Bray-Curtis similarity index was performed, using species incidence data. ANOSIM is a non-parametric permutation procedure that produces a global Rstatistic, which is an absolute measure of distance between groups (Clarke \& Green 1988). An Rvalue approaching 1 indicates strongly distinct assemblages among years, whereas an R-value close to zero indicates that the assemblages are barely separable.

\section{Results}

A total of 31266 ants were collected with 228 pitfall traps throughout the three study seasons. Although mean ant abundance was higher in 2011 than in the following years (Figure 4A), it was very variable among sites, producing only a marginally significant result (i.e., $P=0.06$, Table 1$)$. This variability was caused by some individual traps in two sites

Table 1. Results of blocked ANOVAs for total ant abundance and species richness.

Tabla 1. Resultado los ANOVAs en bloques para abundancia total de hormigas y riqueza específica.

\begin{tabular}{lccccccc}
\hline & \multicolumn{4}{c}{ Total abundance } & \multicolumn{3}{c}{ Species richness } \\
\hline Source & df & SS & F & P & SS & F & P \\
Year & 2 & 3472476 & 3.45 & 0.06 & 0.15 & 0.16 & 0.86 \\
Site (Block) & 7 & 8962820 & 2.55 & 0.06 & 33.57 & 10.30 & $<0.01$ \\
Error & 14 & 7041633 & & & 6.52 & & \\
\hline
\end{tabular}



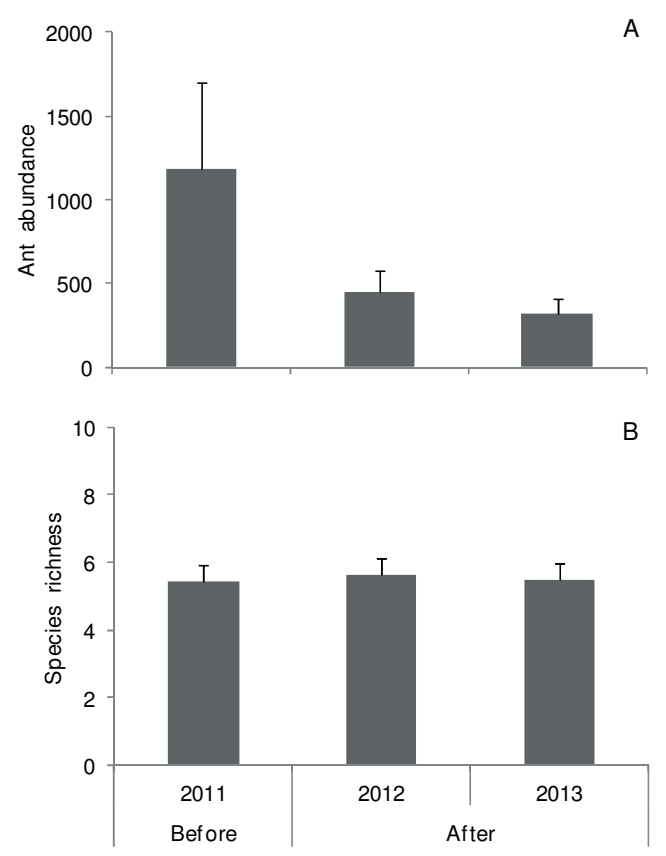

Figure 4. (A) Mean total ant abundance (+SE) and (B) mean species richness (+SE) before (2011) and after (2012 and 2013) the ash fall in the Patagonian steppe. Differences between years were non-significant.

Figura 4. (A) Abundancia promedio de hormigas (+SE) y (B) riqueza específica promedio (+SE) antes (2011) y después (2012) de la caída de cenizas en la estepa patagónica. Las diferencias entre años resultaron no significativas.

which gathered very high numbers $(\sim 1000-$ 3000 individuals/trap) of Dorymyrmex tener and Acromyrmex lobicornis, whose nests seem to be the most populated ones.

Altogether, 13 ant species belonging to three subfamilies and eight different genera were found in the traps. Dorymyrmex tener, D. antarcticus and Brachymyrmex patagonicus were the most abundant ones (Table 2). When species incidence was compared among years, four species showed changes across years. The incidence of B. patagonicus, Lasiophanes valdiviensis and $D$. minutus increased after the eruption. B. patagonicus had the highest incidence in 2012, whereas L. valdiviensis and D. minutus in 2013. The trend was the opposite for $P$. carbonarius, with the lowest incidence in 2013 (Table 2).

No changes in species richness were detected among years. On average, 5.5 species were found per site each year (Figure 4B, Table 1). ANOSIM results indicate that ant assemblages' composition was similar among years (Global $\mathrm{R}=-0.07 ; P=0.87)$.

\section{DisCUSSION}

Ash fall from Puyehue-Cordón Caulle eruption had little effect on ant communities in the Patagonian steppe. Total ant abundance tended to be higher before the eruption but species richness and composition were similar before and in the two seasons following the eruption. An effect was only observed in four out of 13 species found; one species decreased and three increased their incidence. Three of them showed a delay in the response, with noticeable effects arising the second season after the eruption.

Timing was probably crucial for the little effect ash had on ants in the Patagonian steppe. Ash fall from the Puyehue-Cordón Caulle occurred at the end of autumn, when temperatures in the area were already low. Ants in the steppe show null or very low activity during cold months, so there were probably few ants outside their nests during the acute deposition phase. The fact that ants are social insects was vital for their survival and recovery, because even if some foragers may have died during the heavy ash fall, they represent a low percentage of the total

Table 2. Mean incidence $( \pm S E)$ of ant species in pitfall traps ( $N=8$ sites) before (2011) and after (2012 and 2013) ash deposition in the Patagonian steppe. For each row, different letters indicate differences in incidence among years (ANOVA and Tukey's contrasts, $P<0.05$ ).

Tabla 2. Incidencia promedio $( \pm \mathrm{SE})$ de las diferentes especies de hormiga halladas en las trampas de caída ( $\mathrm{N}=8$ sitios) antes (2011) y después (2012 y 2013) de la deposición de ceniza en la estepa patagónica. Para cada fila, las diferentes letras indican diferencias en la incidencia entre años (ANOVA y contrastes de Tukey, $P<0.05$ ).

\begin{tabular}{|c|c|c|c|}
\hline \multirow[b]{2}{*}{ Ant species } & \multirow{2}{*}{$\begin{array}{c}\text { Before } \\
2011\end{array}$} & \multicolumn{2}{|c|}{ After } \\
\hline & & 2012 & 2013 \\
\hline \multicolumn{4}{|l|}{ Dolichoderinae } \\
\hline Dorymyrmex antarcticus Forel & $0.37 \pm 0.13$ & $0.41 \pm 0.14$ & $0.35 \pm 0.13$ \\
\hline Dorymyrmex minutus Emery & $0.19 \pm 0.07^{\mathrm{a}}$ & $0.29 \pm 0.10^{\mathrm{ab}}$ & $0.38 \pm 0.11^{\mathrm{b}}$ \\
\hline Dorymyrmex tener Mayr & $0.71 \pm 0.07$ & $0.69 \pm 0.08$ & $0.66 \pm 0.09$ \\
\hline Dorymyrmex wolffhuegeli Forel & $0.15 \pm 0.06$ & $0.14 \pm 0.06$ & $0.15 \pm 0.06$ \\
\hline \multicolumn{4}{|l|}{ Formicinae } \\
\hline Brachymyrmex patagonica Mayr & $0.49 \pm 0.08^{\mathrm{a}}$ & $0.72 \pm 0.07^{\mathrm{b}}$ & $0.68 \pm 0.07^{\mathrm{ab}}$ \\
\hline Camponotus distinguendus Spinola & $0.01 \pm 0.01$ & 0 & 0 \\
\hline Lasiophanes valdiviensis Forel & $0.09 \pm 0.03^{\mathrm{a}}$ & $0.18 \pm 0.07^{\mathrm{a}}$ & $0.24 \pm 0.10^{b}$ \\
\hline \multicolumn{4}{|l|}{ Myrmicinae } \\
\hline Acromyrmex lobicornis Emery & $0.25 \pm 0.08$ & $0.29 \pm 0.12$ & $0.24 \pm 0.09$ \\
\hline Pheidole spininodis Mayr & $0.14 \pm 0.07$ & $0.21 \pm 0.09$ & $0.14 \pm 0.05$ \\
\hline Pogonomyrmex carbonarius Mayr & $0.31 \pm 0.07^{\mathrm{a}}$ & $0.21 \pm 0.07^{\mathrm{a}}$ & $0.07 \pm 0.02^{\mathrm{b}}$ \\
\hline Solenopsis patagonica Emery & 0 & $0.02 \pm 0.02$ & $0.06 \pm 0.04$ \\
\hline Solenopsis richteri Forel & $0.02 \pm 0.02$ & $0.01 \pm 0.01$ & $0.02 \pm 0.02$ \\
\hline Solenopsis sp. & $0.08 \pm 0.04$ & $0.06 \pm 0.04$ & $0.04 \pm 0.03$ \\
\hline
\end{tabular}


population of a colony (Nobua Behrmann et al. 2013). Also, queens usually dwell deep inside the nests, so they were probably not directly affected by ash fall, guaranteeing the replacement of workers and the survival of the colony. Observations of pre-marked colonies (especially of Pogonomyrmex carbonarius and Acromyrmex lobicornis) three months after the eruption indicate that although covered with ash, they were active and many workers were involved in nest maintenance (G. Pirk, personal observation). Akre et al. (1981) reported similar responses of ants in areas affected by Mt. St. Helens ash fall. Although loss of foragers was observed in the initial ash fall, foraging activity of Formica colonies in the ash layer throughout the summer was similar to that of ash free areas.

Not all social insects, however, have the same advantages as ants. Contrary to ants, Vespula spp. populations, which were devastated in areas with similar ash thickness (Masciocchi et al. 2013), have annual colonies founded in the spring by overwintering queens. These queens hibernate in protected places, which were probably buried under the ash, killing them or complicating their emergence in spring. In this case, the timing of the eruption affected a crucial stage of wasp's life cycle. Thus, the interaction between timing and insect taxon seems to be critical in determining the outcome of insect populations affected by ash.

Ash thickness in the Patagonian steppe (i.e., $\sim 4 \mathrm{~cm}$ ) may not have been high enough to significantly affect ant survival. In the few studies available, it seems that there is a threshold above which ants are negatively affected by ash. Ash quantities showed a negative effect on canopy ant numbers on the island of Montserrat. However, this effect was not observed at leaf ash levels $<500 \mathrm{mg} /$ $\mathrm{m}^{2}$ indicating that ants might be resistant to smaller quantities of ash (Marske et al. 2007). Observations of ant species richness two years after the eruption of Mt. St. Helens showed that there were 9 species where tephra layer was $\sim 15 \mathrm{~cm}$, but only one where the layer was $\sim 50 \mathrm{~cm}$ (Edwards 1986). Hence, the PuyehueCordón Caulle eruption may have had a more devastating effect on ants in the forests closer to the vent, where ash layer reached $30 \mathrm{~cm}$ (Gaitán et al. 2011).

Species richness and composition did not change either in the first or second season after the eruption of the Puyehue-Cordón
Caulle. However, there were four species which changed their incidence: Pogonomyrmex carbonarius decreased its incidence while Lasiophanes valdiviensis, Dorymyrmex minutus and Brachymyrmex patagonicus increased it. There is no evidence of differential susceptibility to ash in these species. Small species are expected to dehydrate faster when exposed to ash (Wille \& Fuentes 1975), but $P$. carbonarius is one of the largest in the ant community, L. valdiviensis and D. minutus are of intermediate size, and B. patagonicus is the smallest one. Also, none of them has a cuticle which may cause a different type of exposure to ash and they all nest in the soil (G. Pirk, personal observation). Indirect effects of ash, mediated by resource and environmental changes, and ant behavior, could explain the patterns observed. Colonies of the harvester ant $P$. carbonarius may have retained their activity in spite of the lack of resources by using seeds stored in granaries; however, worker mortality may have increased and/or colony activity decreased to avoid energy expenditure as seed stores ran out. As for the other three species, their generalized diet (Kusnezov 1959; Fergnani et al. 2013) may have allowed them to exploit a broad range of resources after the ash fall. Also, the lack of resources may have forced them to increase their foraging areas which could explain their presence in a higher proportion of traps. Notwithstanding, it has to be taken into account that due to the nature of the phenomenon under study, among-year environmental variation could not be controlled. Thus, this variation and chance alone could explain the changes in incidence of these species. However, sampling was designed to minimize these confounding factors by performing it in similar periods on every season and avoiding meteorological events such as strong winds or rainfall to make field conditions comparable, and by placing the traps in the same spots each year. Moreover, the effects of a $4-\mathrm{cm}$ ash cover in such a broad area is likely to be much more significant than natural environmental variation or chance.

The effects of volcanic activity on ant communities can be compared to those of fire, a well- studied natural disturbance. Fires can simplify environments and affect in turn ant community attributes. In particular, they can affect ant assemblages indirectly through modifications to habitat, food supplies, microclimatic variables and interspecific 
competition (Andersen 1991; York 2000; Farji-Brener et al. 2002). In steppe areas of the Patagonia, however, fire did not affect ant diversity as opposed to shrublands where it decreased (Farji-Brener et al. 2002). The lack of an effect in the steppe was attributed to the fact that the low vegetation regenerated rather rapidly after the fire, and consequently, firerelated changes for ants are probably small and short term. Thus, ants inhabiting the steppe may be resistant not only to moderate amounts of volcanic ash, but also to other natural disturbances such as fires.

Although this study shows almost no effects of ash on ant communities after two years of the eruption, long-term effects cannot be discarded. Colonies may be able to deal with the lack of resources, replacement of dead workers and nest maintenance activities, during the first seasons, but this may compromise colony reproduction. Reproductive output and proportion of biomass allocated to reproduction versus growth depends, among other factors, on energy available and food quantity and quality (Herbers \& Banschbach 1998). Thus, colonies affected by ash fall may be able to survive but not to reproduce, limiting population growth. These effects, however, would probably be noticeable after more than two seasons. Also, indirect effects as observed in four species may take longer to be detectable in other species. Long-term monitoring of ant communities in the Patagonian steppe would confirm if this ash fall was actually almost innocuous to ants.

In conclusion, thanks to the availability of baseline data, which is lacking in most studies on the effects of volcanoes on insects, this study shows that ants were in general resistant to ash fall from Puyehue-Cordón Caulle. In an area where volcanic eruptions are relatively frequent the fact that ants, involved in many interactions and ecosystems processes, are resistant to ash fall implies a rapid recovery of steppe communities from this type of natural disturbance.

Acknowledgements: I am grateful to F. Milesi, L. Elizalde, two anonymous reviewers and the associate editor A. Ruggiero, whose comments helped to improve the manuscript. L. Aput, M. Carruitero and S. Ilera gave valuable help in the field. L. Aput and M. Carruitero aided in the laboratory as well. P. Fergnani and V. Werenkraut helped with ant identification. I also thank F. Oddi for helping with the map. Financial support was supplied by Agencia Nacional de Promoción Científica y Tecnológica of Argentina (PICT 2008-0352).

\section{REFERENCES}

AKRe, RD; LD HANSEN; HC REEd \& LD CoRpus. 1981. Effects of volcanic ash from Mt. St. Helens on ants and yellow jackets. Melanderia, 37:1-19.

ANDERSEN, A. 1991. Responses of ground-foraging ant communities to three experimental fire regimes in a savanna forest of tropical Australia. Biotropica, 23: 575-585.

ARENDT, WJ; DW GibBons \& GAL Gray. 1999. Status of the volcanically threatened Montserrat Oriole Icterus oberi and other forest birds in Montserrat, West Indies. Bird Conserv. Int., 9:351-372.

BROWN, JJ \& Y BIN Hussain. 1981. Physiological effects of volcanic ash upon selected insects in the laboratory. Melanderia, 37:30-38.

Buteler, M; T Stadler; GP López García; MS Lassa; D Trombotto Liauda; et al. 2011. Propiedades insecticidas de la ceniza del complejo volcánico Puyehue-Cordón Caulle y su posible impacto ambiental. Rev. Soc. Entomol. Argent., 70:149-156.

Clarke, KR \& RH Green. 1988. Statistical design and analysis for a "biological effects" study. Mar. Ecol-Prog. Ser., 46:213-226.

CORREA, MN.1969-1998. Flora Patagónica. Instituto Nacional de Tecnología Agropecuaria, Buenos Aires.

Dale, VH; CM Crisafulli \& FJ Swanson. 2005. 25 years of ecological change at Mount St. Helens. Science, 308: 961-962.

EDWARDS, JS. 1986. Arthropods as pioneers: recolonization of the blast zone on Mt. St. Helens. Northwest Environ. J., 2:63-73.

EdWARDS, JS \& LM Schwartz. 1981. Mount St. Helens ash: a natural insecticide. Can. J. Zool., 59:714-715.

FARJI-BRENER, AG. 1996. Posibles vías de expansión de la hormiga cortadora de hojas Acromyrmex lobicornis hacia la Patagonia. Ecol. Austral, 6:144-150.

Farj-Brener, AG; JC Corley \& J Bettinelli B. 2002. The effects of fire on ant communities in north-western Patagonia: the importance of habitat structure and regional context. Divers. Distrib., 8:235-243.

Fergnani, PN; P SAckmann \& A Ruggiero. 2013. The spatial variation in ant species composition and functional groups across the Subantarctic-Patagonian transition zone. J. Insect Conserv., 17:295-305.

FernándeZ-Arhex, V; M. Buteler; ME AMAdio; A EnRiQuez; AL PietrantuONO; ET AL. 2013. The effects of volcanic ash from Puyehue-Caulle Range eruption on the survival of Dichroplus vittigerum (Orthoptera: Acrididae). Fla. Entomol., 96:286-288.

GAITÁN, JJ; JA AYesa; F UMAÑa; F RAFFo \& DB BRAN. 2011. Cartografía del área afectada por cenizas volcánicas en las provincias de Río Negro y Neuquén. Informe Técnico. Instituto Nacional de Tecnología Agropecuaria (INTA), Estación Experimental S.C. de Bariloche.

Ghermandi, L \& S GonzÁlez. 2012. Observaciones tempranas de la deposición de ceniza por la erupción volcánica del Cordón Caulle y sus consecuencias sobre la vegetación de la estepa del NO de la Patagonia Ecol. Austral, 22:144-149.

Grishin, SY; R del Moral; P KRestov \& VP VerkHolat. 1996. Succession following the catastrophic eruption of Ksudach volcano (Kamchatka, 1907). Vegetatio, 127: 129-153.

Halpern, CB; PM Frenzen; JE Mean \& JF Franklin. 1990. 
Plant succession in areas of scorched and blown-down forest after the 1980 eruption of Mount St. Helens, Washington. J. Vegetation Sci., 1:181-194.

Herbers, JM \& VS Banschbach. 1998. Food supply and reproductive allocation in forest ants: repeated experiments give different results. Oikos, 83:145-151.

Klostermeyer, EC; LD Corpus \& CL Campbell. 1981. Population changes in arthropods in wheat following volcanic ash fallout. Melanderia, 37:45-49.

Kusnezov, N. 1959. La fauna de hormigas en el oeste de la Patagonia y Tierra del Fuego. Acta Zool. Lilloana, 17: 321-401.

Kusnezov, N. 1978. Hormigas argentinas: clave para su identificación. Fundación Miguel Lillo, Tucumán, Argentina.

Marske, KA; MA Ivie \& GM HiLoton. 2007. Effects of volcanic ash on the forest canopy insects of Montserrat, West Indies. Environ. Entomol., 36:817-825.

Martínez, AS; M Masciocchi ; JM Villacide; G Huerta; L DANERI; ET AL. 2013. Ashes in the air: the effects of volcanic ash emissions on plant-pollinator relationships and possible consequences for apiculture. Apidologie, 44: 268-277.

Masciocchi, M; AJ Pereira; MV Lantschner \& JC Corley. 2013. Of volcanoes and insects: the impact of the PuyehueCordon Caulle ash fall on populations of invasive social wasps, Vespula spp. Ecol. Res., 28:268-277.
Nobua Behrmann, BE; J Lopez de Casenave; FA Milesi \& B PAVAN. 2013. Forager abundance and its relationship with colony activity level in three species of South American Pogonomyrmex harvester ants. Insect. Soc., 60:243-249.

Pickett, STA \& PS White. 1985. The ecology of natural disturbance and patch dynamics. Academic Press, New York.

SAMways, MJ; R Osborn \& F CARLIEL. 1997. Effect of highway on ant (Hymenoptera: Formicidae) species composition and abundance, with a recommendation for roadside verge width. Biodivers. Conserv., 6:903-913.

SINGER, BS; BR JiCHA; MA HARPER; JA NARANJO; LE LARA; ET AL. 2008. Eruptive history, geochronology, and magmatic evolution of the Puyehue-Cordón Caulle volcanic complex, Chile. Geol. Soc. Am. Bull., 120:599-618.

SNelling, RR \& JH Hunt. 1975. The ants of Chile (Hymenoptera: Formicidae). Rev Chil Entomol., 9:63-129.

Turner, MG; VH Dale \& EH Everham. 1997. Fires, hurricanes, and volcanoes: comparing large disturbances. BioScience, 47:758-768.

WiLle, A \& G Fuentes. 1975. Efecto de la ceniza Volcán Irazú (Costa Rica) en algunos insectos. Rev. Biol. Trop, 23:165-175.

YORK, A. 2000. Long-term effects of frequent low-intensity burning on ant communities in coastal blackbutt forests of southeastern Austalia. Austral Ecol., 25:83-98. 